\title{
PEMAKNAAN NORMA KONSTITUSI DALAM PENGUATAN DEWAN PERWAKILAN DAERAH DALAM RULE MAKING FUNCTION
}

\author{
Adhitya Widya Kartika \\ Universitas Pembangunan Nasional Veteran Jawa Timur \\ Jalan Raya Rungkut Madya Gunung Anyar, Surabaya \\ Email: adhityawidyakartika@ymail.com
}

\begin{abstract}
The existence of the House of Representatives (DPD) in including regional inputs in the form of norms has experienced polemics. These polemics include the decisions of the State Administrative Court (PTUN), the Supreme Court (MA), and the Constitutional Court (MK) that are out of sync with one another. This decision has the impact of legal dualism which results in confusion for the General Election Commission (KPU) to carry out its functions and even disharmony between legal norms. This normative research aims to determine the existence of a basis to support the DPD in order to reduce conflicts of interest. As a result, the KPU, when viewed from the normative aspect, the Constitutional Court is the sole interpreter of the constitution because of the authority granted by the constitution in Article $24 \mathrm{C}$. If so, then the $K P U$ does not have to worry about implementing the Constitutional Court's decision because it is constitutional. That is, the KPU carrying out the Constitutional Court's Decision means maintaining the dignity of the DPR so that the aspirations carried out truly represent the needs of the region without worrying about conflicts of interest because they have as administrators of political parties.
\end{abstract}

Key words: constitutional intrepertation, conflicts of interest, legislative drafting

\begin{abstract}
Abstrak
Eksistensi Dewan Perwakilan Daerah (DPD) dalam memasukkan aspirasi daerah dalam bentuk norma mengalami polemik. Polemik ini diantaranya adanya Putusan Pengadilan Tata Usaha Negara (PTUN), Mahkamah Agung (MA), serta Mahkamah Konstitusi (MK) yang tidak sinkron antara satu dengan lainnya. Putusan tersebut membawa dampak adanya dualisme hukum yang berkakibat pada kebingungan Komisi Pemilihan Umum (KPU) untuk menjalankan fungsinya bahkan terjadi inkonsistensi norma sehingga terjadi ketidak-harmonisan antar norma hukum. Penelitian normatif bertujuan mengetahui eksistensi penafsiran konstitusi untuk penguatan DPD demi mengurangi konflik kepentingan. Hasilnya, KPU, apabila dilihat dari aspek penormaan, MK merupakan penafsir tunggal konstitusi karena kewenangannya yang diberikan oleh konstitusi pada Pasal 24 C karena kedudukan norma dasar maka Putusan PTUN menjadi inkonstitusional. Jika demikian maka KPU tidak perlu kawatir dalam menjalankan Putusan MK karena konstitusional. Artinya, KPU apabila menjalankan Putusan MK berarti mempertahankan marwah DPR sehingga aspirasi yang diusung benar-benar mewakili kebutuhan daerah tanpa khawatir adanya konflik kepentingan karena menjabat sebagai pengurus partai politik.
\end{abstract}

Kata kunci: Penafsiran konstitusi, konflik kepentingan, fungsi legislatif 


\section{Latar Belakang}

Indonesia penganut negara hukum yang berarti semua perbuatan hukum pemerintah harus beradasarkan hukum dan hukum juga berarti wujud perlindungan pemerintah kepada masyarakat. Hukum yang dibentuk hendaknya mencerminkan keadilan, kemanfaatan dan kepastian hukum berdasarkan asas yuridis, sosiologis dan filosofis. Selain itu hukum juga diharapkan dapat memenuhi kebutuhan hukum yang ada di masyarakat karena itu semakin lengkap atau mengakomodasi aspirasi masyarakat dan daerah maka hukum yang ditimbulkan semakin mendekati dengan apa yang dicitakan dalam kehidupan bernegara. Indonesia, dalam hal legislative drafting mmemiliki perwakilan yaitu Dewan Perwakilan Rakyat dan Dewan Perwakilan Daerah. Dewan Perwakilan Rakyat dan Dewan Perwakilan Daerah adalah lembaga legislatif yang dimiliki Indonesia sebagai representatif kebutuhan masyarakat dana kepentingan daerah. Dewan Perwakilan Rakyat sebagai perwakilan atas kepentingan masyarakat dan Dewan Perwakilan Daerah sebagai perwakilan dari kepentingan Daerah sehingga keduanya memiliki peran yang berbeda dan saling melengkapi dan menambah lengkapnya aspirasi yang akan disusun menjadi norma hukum. Kedua lembaga itu (Dewan Perwakilan Rakyat dan Dewan Perwakilan Daerah) memiliki fungsi legislatif dengan bidang yang berbeda (pencerminan pembagian kekuasaan) dengan demikian agar tidak terjadi kesewenang- wenangan pada norma hukum yang dibuat maka diperlukan prinsip checks and balances diantara keduanya yang timbul dengan adanya "saling menilai" sehingga saling melengkapi dan mengevaluasi pelaksanaan fungsi.

Persoalan yang terjadi adalah ketika terjadi polemik terhadap seleksi untuk masuk menjadi anggota Dewan Perwakilan Rakyat. Polemik tersebut berkaitan dengan calon peserta pemilihan umum anggota Dewan Perwakilan Daerah berkaitan dengan peserta yang menjadi pengurus partai politik. Polemik ini dikhawatirkan akan menimbulkan konflik kepentingan ketika anggota Dewan Perwakilan Daerah menjalankan fungsinya (legislatif). Peristiwa ini semakin rumit mana kala terdapat putusan lembaga pengadilan yang berbeda antara dua instansi pengadilan sehingga timbul kegaduhan norma yang berakibat mengganggu fungsi dari Komisi Pemilihan Umum. Putusan pengadilan yang dimaksud adalah Pengadilan Tata Usaha Negara, Mahkamah Agung, dan Mahkamah Konstitusi. Putusan Mahkamah Konstitusi Nomor 30/PUU-XVI/2018 yang menetapkan bahwa syarat bakal calon bagi anggota Dewan Perwakilan Daerah antara lain tidak menjadi pengurus (fungsionaris) partai politik yang terhitung sejak Pemilihan Umum pada Tahun 2019 dan sesudahnya. Lain halnya dengan Putusan pada Mahkamah Agung Republik Indonesia Nomor $65 \mathrm{P} / \mathrm{HUM} / 2018$ dan putusan terkait Penetapan Daftar Calon Tetap (DCT) anggota Dewan Perwakilan Daerah oleh Komisi Pemilihan Umum pada Pengadilan 
Tata Usaha Negara Jakarta Nomor 242/G/ SPPU/2018/PTUN.JKT yang putusannya bertentangan dengan Putusan Mahakamah Konstitusi. Putusan Mahkamah Agung dan Putusan Pengadilan Tata Usaha Negara terkait dengan pengajuan permohonan oleh bakal calon anggota Dewan Perwakilan Daerah yang merupakan pengurus partai politik dan dikabulkan. Persoalan ini sangat penting mengingat merupakan hal yang penting dalam negara demokrasi (terkait dengan pemilihan umum) oleh karenanya penulis tertarik untuk menganalisis terkait pemaknaan norma dalam konstitusi untuk memperkuat fungsi Dewan Perwakilan Daerah dalam situasi tidak adanya kepastian hukum karena perbedaan norma dalam putusan. Rumusan masalah yang dapat ditarik yaitu bagaimana Pemaknaan Norma Konstitusi dalam Penguatan Dewan Perwakilan Daerah dalam Rule Making Function.

Penelitian hukum ini menggunakan studi dokumen yaitu meneliti data sekunder. Jenis penelitian ini merupakan penelitian hukum normatif dengan menggunakan beberapa pendekatan antara lain pendekatan peraturan perundang-undangan, pendekatan historis, pendekatan kasus, pendekatan perbandingan hukum, dan pendekatan doktrin. Pendekatan peraturan perundang-undangan yaitu menggunakan peraturan perundang-undangan untuk menelaah permasalahan yang terkait dengan penelitian ini misalnya terkait dengan putusan dan peraturan perundang-undangan terkait. Selain itu, menggunakan Pendekatan konseptual yaitu menelaah rumusan dan data dengan menggunakan doktrin-doktrin atau teori terkait misalnya Mahkamah Konstitusi, Sistem Perwakilan, dan Norma. Sumber data yang digunakan adalah data sekunder sehingga menggunakan metode kepustakaan dengan bahan hukum primer dan sekunder, yang mana Data sekunder menjelaskan data primer. Tehnik pengumpulan yang digunakan adalah studi kepustakaan dengan dianalisis menggunakan metode kualitatif sehingga dapat ditarik kesimpulan. Penelitian yang diteliti sebelumnya (sebelum penelitian Pemaknaan Norma Konstitusi dalam Penguatan Dewan Perwakilan Daerah dalam Rule Making Function dipublikasikan) terdapat beberapa aspek yang telah diteliti sebelumnya (previous research) antara lain yang pertama oleh Pan Mohamad Faiz dan Muhammad Reza Winata dengan artikel berjudul Respons Konstitusional Larangan Calon Anggota Dewan Perwakilan Daerah sebagai Pengurus Partai Politik yang meneliti terkait finalitas putusan, respon, serta validitas norma dengan hasil penelitian bahwa karakter Putusan Mahkamah Agung dan Mahkamah Konstitusi sama yaitu erga omnes serta karekter putusan Bawaslu dan Pengadilan Tata Usaha Negara adalah sama mengikat para pihak sehingga mengikat Komisi Pemilihan Umum dan respon Komisi Pemilihan Umum menegakkan putusa Mahkamah Konstitusi merupakan respon konstitusional. ${ }^{1}$ Kedua,

1 Pan Mohamad Faiz dan Muhammad Reza Winata, Respons Konstitusional Larangan Calon Anggota Dewan Perwakilan Daerah sebagai Pengurus Partai Politik (Constitutional Response Concerning the Prohibition for Regional Representative Council Candidates as Political Party Officials), Jurnal Konstitusi Volume 16, Nomor 3, (September 2019). hlm. 532-558. 
oleh Tohadi, Dian Eka Prastiwi, dan Reni Suryani dengan artikel berjudul Larangan Pengurus (Fungsionaris) Partai Politik sebagai Bakal Calon Anggota Dewan Perwakilan Daerah pada Pemilu 2019 yang meneliti terkait pertimbangan hakim pada putusan terkait larangan pengurus partai untuk bakal calon Dewan Perwakilan Daerah dan sebab perbedaan pertimbangan putusan Mahkamah Agung dan Mahkamah Konstitusi dengan hasil penelitian tidak diperbolehkannya pengurus partai untuk bakal calon Dewan Perwakilan Daerah dan diberlakukan Pemilu 2019 dan putusan Mahkamah Agung tidak berlaku serta pembedaan pertimbangan Mahkamah Agung dan Mahkamah Konstitusi karena terdapat perbedaan penafsiran terkadap tahapan proses pencalonan anggota Dewan Perwakilan Daerah. ${ }^{2}$ Aspek yang dikaji dalam penelitian Pemaknaan Norma Konstitusi dalam Penguatan Dewan Perwakilan Daerah dalam Rule Making Function belum ada dalam kajian kedua penelitian tersebut.

\section{Pembahasan}

Undang-Undang Dasar Negara Republik Indonesia Tahun 1945 merupakan konstitusi tertulis yang menjadi dasar bernegara di negara Indonesia, maka dalam kehidupan bernegara harus sesuai dengan norma yang terkandung dalam konstitusi. Konstitusi merupakan dasar hukum bernegara yang utama pada setiap negara termasuk adalah negara hukum. Pasal 1 ayat (3) dalam Undang- Undang Dasar Negara Republik Indonesia Tahun 1945 menegaskan bahwa Negara Hukum merupakan anutan di negara Indonesia dan hal ini merupakan konsekuensi agar hukum diterapkan sebagaimana mestinya. Eksistensi negara hukum pada konstitusi ini menimbulkan konsekuensi bahwa tidak hanya pemerintah tetapi masyarakat harus taat pada hukum yang berlaku.

Ada banyak konsep negara hukum di dunia, diantaranya Negara Hukum rechtsstaat dan the rule of law. Masing-masing negara hukum itu sesungguhnya memiliki karakter yang berbeda satu sama lain, tetapi pada perkembangannya terjadi suatu akulturasi antara keduanya sehingga negara yang awalnya memiliki sistem yang berbeda sama sekali justru terjadi pencampuran karakteristik. Negara-negara yang awalnya mengikuti sistem rechtsstaat kemudian menerapkan unsur-unsur yang ada pada sistem the rule of law karena perkembangan hukum membutuhkan unsur-unsur yang ada pada sistem negara hukum yang lainnya. Begitu pula negara hukum yang diterapkan di Indonesia, bahwa Indonesia menganut prinsip rechtsstaat karena sebelum amandemen dan penjelasan Undang-Undang Dasar Negara Republik Indonesia Tahun 1945 ketika masih berlaku diketahui bahwa dalam Penjelasan Undang-Undang Dasar Negara Republik Indonesia Tahun 1945 negara hukum dengan

2 Tohadi, Dian Eka Prastiwi, dan Reni Suryani, Larangan Pengurus (Fungsionaris) Partai Politik sebagai Bakal Calon Anggota Dewan Perwakilan Daerah pada Pemilu 2019, Jurnnal Surya Kencana Satu: Dinamika Masalah Hukum dan Keadilan Volume 11 Nomor 2 (Oktober 2021). hlm. 193-208. 
diksi rechtstaat dalam tanda kurung yang berarti negara hukum yang dianut Indonesia adalah negara hukum rechtsstaat. Misalnya, negara hukum Indonesia apabila dilihat dari aspek judicial system maka akan terlihat adanya peradilan tata usaha negara. Namun, seiring perkembangan sistem hukum yang terjadi, setelah amandemen, diksi negara hukum tidak kaku pada rechtsstaat karena penjelasan tidak berlaku lagi sehingga terlepas dari diksi rechtsstaat dengan tanda kurung, sehingga terdapat kemungkinan pencampuran antara rechtsstaat dan the rule of law atau mengambil unsur sistem negara hukum lain atau memiliki karakteristik tersendiri. Perlu diketahui kajian terhadap penjelasan UndangUndang Dasar Negara Republik Indonesia Tahun 1945 masih diperlukan untuk melihat aspek historis dan hakikat pembentukan norma. Penjelasan merupakan tafsir resmi suatu noorma dalam peraturan. ${ }^{3}$

Konsekuensi adanya negara hukum maka perbuatan pemerintah yang terkait dengan kegiatan pemerintahan pun harus sesuai dengan hukum. Peraturan perundangundangan merupakan salah satu hukum tertulis tidak hanya dimaksudkan untuk social control yang mengatur kehidupan bermasyarakat tetapi juga untuk melindungi masyakat dari kesewenang-wenangan pemerintah. Penting untuk diketahui bahwa suatu hukum dapat diterapkan untuk membatasi perilaku masyarakat agar terjadi suatu keadaan yang tertib tetapi tidak serta merta hukum yang diterapkan itu melindungi masyarakat apabila dalam hukum sendiri terjadi kesewenangan dari pemerintah. Misalnya, dalam hukum itu terdapat unsur legitimasi kesewenangwenangan pemerintah atau penguasa sehingga produk hukum yang ditimbulkan tidak mencerminkan prinsip keadilan dalam masyarakat bahkan tidak ada manfaat atau kepastian atau justru merugikan masyarakat karena hal inilah perlunya aspirasi masyarakat dalam sistem negara hukum. Oleh karena itu, penting kiranya untuk mengumpulkan aspirasi masyarakat sebagai wujud adanya perlindungan pemerintah kepada masyarakat. Masuknya aspirasi masyarakat ini berkaitan pula dengan sistem pembagian, pemisahan serta evaluasi kekuasaan. Selain menjamin masuknya aspirasi masyarakat dalam suatu sistem norma hukum penting tentunya penerapan sistem pemisahan dan pembagian kekuasaan serta checks and balances untuk menjamin tidak adanya super power dalam satu badan dalam suatu negara. Teori pemisahan kekuasaan dan pembagian kekuasaan dikenal dengan adanya Eksekutif, Legislatif dan Yudikatif. Konsep ini apabila tidak terdapat pemisahan maupun pembagian maka yang terjadi adalah adanya sewenangwenangan atau absolutisme yang berujung penyalahgunaan wewenang. Hal ini seperti Montesquie, The accumulation of all powers, legislative, executive, and judiciary, in the

3 Bagus Hermanto, Nyoman Mas Aryani, Ni Luh Gede Astariyani, Penegasan Kedudukan Penjelasan Suatu Undang-Undang: Tafsir Putusan Mahkamah Konstitusi, Jurnal Legislasi Indononesia Volume 17, Nomor 3, (September 2020). hlm. 251-268. 
same hands, wether of one, a few, or many, and wether hereditary, self appointed, or elective, may justly be pronounces the very defintion of tyrany. ${ }^{4}$ Akumulasi kekuasaan juga dapat terjadi dalam tubuh legislatif pada Indonesia antara Dewan Perwakilan Rakyat Dengan Dewan Perwakilan Daerah. Kekuasaan pembentukan peraturan perundang-undangan pada tingkat Undang-undang diberikan kepada Legislatif. Produk hukum pada tingkat Undang-Undang perlu adanya persetujuan antara Presiden dengan Dewan Perwakilan Rakyat sebagai wakil dari rakyat dan dalam hal menyusun undang-undang tertentu diperlukan peran serta dari Dewan Perwakilan Daerah yang mewakili akan kebutuhan-kebutuhan daerah.

Pada prakteknya di Indonesia mengenal adanya sistem perwakilan rakyat pada lembaga legislatifnya. Kemauan rakyat tidak akan memiliki predikat norma apalagi bersifat imperatif yang berfungsi sebagai dasar atau patokan penyelenggaraan negara tanpa dirumuskan secara khas oleh lembaga legislatif. $^{5}$ Lembaga legislatif ini yang diharapkan mampu mewakili semua aspirasi masyarakat dan kebutuhan pada masingmasing daerah di seluruh Indonesia dengan adanya Dewan Perwakilan Rakyat dan Dewan Perwakilan Daerah. Hal pembagian urusan pemerintahan terdapat pada saat pembuatan peraturan perundang-undangan khususnya undang-undang. Pembuatan undang-undang sebelum pengesahan diperlukan pembahasan antara Presiden dengan Dewan Perwakilan Rakyat dalam hal tertentu perlu dibahas dengan Dewan Perwakilan Daerah. Hanya saja kewenangan antara Dewan Perwakilan Rakyat dengan Dewan Perwakilan Daerah itu berbeda. Dewan Perwakilan Rakyat ikut membahas bahkan sampai pada mengesahkan, sedangkan Dewan Perwakilan Daerah hanya berpartisipasi sampai pada pembahasan saja tidak ikut serta dalam pengesahan. Kewenangan Dewan Perwakilan Daerah tidak begitu sebanyak Dewan Perwakilan Rakyat. Walaupun demikian keduanya berperan dalam hal menyalurkan aspirasi masyarakat dan daerah. Fungsi sebatas pengusulan rancangan undang-undang dapat dikatakan lembaga legislative tidak penuh yang dapat mengurangi penjaminan tertampungnya aspirasi daerah dapat dikatakan situasi aspirasi daerah adalah lemah. ${ }^{6}$ Artinya, mandate yang dijalankan yang merupakan wewenang Dewan Perwakilan Daerah terdapat ketidakefektifan terkait dengan kepentingan daerah karena terkait legislasi tergantung pada Dewan Perwakilan Rakyat. ${ }^{7}$ Pada fungsi legislasi Dewan Perwakilan Rakyat tidak memiliki

4 Geoffrey Brennan and Alan Haamlin, Democratic Devices and Desires, Theories of Institutional Design, (Cambridge, Cambridge University Press 2000). p. 233.

5 Margarito Kamis, Jalan Panjang Konstitusionalisme Indonesia, (Malang, Setara Press, 2014). hlm. 1.

6 Anwar Jasie, Dewan Perwakilan Daerah Lembaga Legislatif Tanpa Legislasi, Khazanah Hukum Volume 2, Nomor 1, (April 2020). hlm. 1-9.

7 Khamami Zada, Kewenangan Legislasi Dewan Perwakilan Daerah dalam Reformasi Kelembagaan Perwakilan Pasca Putusan Mahkamah Konstitusi, Jurnal Cita Hukum, FSH UIN Syarif Hidayatullah Jakarta Volume 3, Nomor 1, (Juni 2015). hlm. 25-38. 
zelfstandigheid dalam mengambil keputusan hukum. ${ }^{8}$

Pembahasan berkaitan dengan sistem kewenangan dalam pembentukan peraturan perundang-undangan di atas diperlukan pemurnian dalam hal menyampaikan aspirasi masyarakat dan daerah agar tidak terjadi dominasi aspirasi sehingga mengaburkan aspirasi yang betul-betul berasal dari masyarakat maupun daerah. Upaya ini diwujudkan dengan adanya persyaratanpersyaratan yang menjadi syarat dalam sistem penjaringan calon-calon anggota Dewan Perwakilan Daerah sehingga tujuan awal dibentuknya suatu lembaga Dewan Perwakilan Daerah benar-benar mewakili aspirasi dan kebutuhan daerah. Eksistensi Dewan Perwakilan Daerah ini pun terjadi beberapa keinginan untuk merubah dari bagian-bagian daripada Dewan Perwakilan Daerah. Seperti yang dapat diketahui bahwa menurut BAB VII A Amandemen Ketiga tentang Dewan Perwakilan Daerah dalam Undang-Undang Negara Republik Indonesia tahun 1945 bahwa Dewan Perwakilan Daerah memiliki tugas dan fungsi yang telah diatur diantaranya pada ayat (1) bahwa Dewan Perwakilan Daerah dapat mengajukan kepada Dewan Perwakilan Rakyat rancangan undangundang yang berkaitan dengan otonomi darah, hubungan pusat dan daerah, pembentukan dan pemekaran serta penggabungan daerah, pengelolaan sumber daya alam dan sumber daya ekonomi lainnya serta yang berkaitan dengan perimbangan keuangan pusat dan daerah. Kewenangan ini sudah dapat dilihat perbedaannya dengan Dewan perwakilan Rakyat yang tidak ditentukan rancangan undang-undang apa saja yang menjadi kewenangan Dewan Perwakilan Rakyat sehingga dapat dilihat perbedaan antara keduanya dimana Dewan Pehrwakilan Daerah dapat menginisiasi rancangan undang-undang yang bersifat kedaerahan. Begitu juga dengan pembahasan rancangan undang-undang tidak semua rancangan undang-undang dibahas dengan Dewan Perwakilan Daerah karena hanya hal-hal tertentu saja. Dewan Perwakilan Daerah dapat mengajukan rancangan undangundang pun harus melalui Dewan Perwakilan Rakyat, rancangan ini berkaitan dengan otonomi daerah hubungan pusat dan daerah serta lainnya yang bersifat kedaerahan (halhal ditentukan dalam Undang-Undang Dasar Negara Republik Indonesia Tahun 1945 Amandemen Ketiga), ikut membahas dan melakukan pengawasan tetapi tidak dalam hal menyetujui dan mengesahkan sesuai dengan Pasal 22 D ayat (1), ayat (2), dan ayat (3) Undang-Undang Dasar Negara Republik Indonesia Tahun 1945 Amandemen Ketiga.

Pengaturan dalam konstitusi mengenai Dewan Perwakilan Rakyat dan Dewan Pewakilan Daerah pada kenyataannya mengalami ketidakseimbangan, padahal Indonesia satu sisi menginginkan adanya 
sistem bikameral model Indonesia tetapi yang justru terlihat disini adalah adanya legislative heavyatau dapatdikatakan dominasikekuasaan Dewan Perwakilan Rakyat sehingga terlihat soft bikameral dan bukan bikameral murni. Joko J Prihatmoko, sisem bicameral terdapat dua lembaga perwakilan yang masingmasing bekerja dan memainkan jenis yang berbeda.... ${ }^{9}$ Giovanni Sartori, tiga jenis sistem bikameral yaitu asymetric (kekuatan salah satu kamar jauh lebih dominan atas kamar lainnya), symmetric bicameralism kekuatan antara dua kamarnya nyaris sama kuat, dan perfect bicameralism kedua kamarnya seimbang. ${ }^{10}$ Seperti pendapat Prof. Enny, Dewan Perwakilan Daerah sebagai bagian dari parlemen Indonesia tetap mencerminkan sifat soft becameralism walaupun disebut sebagai lembaga negara tetapi kedudukan tetap tidak setara dengan Dewan Perwakilan Rakyat. ${ }^{11}$ Apabila dilihat dari fungsinya dalam satu badan Majelis Permusyawaratan Rakyat maka bikameral yang ada pada Dewan Perwakilan Rakyat maupun Dewan Perwakilan Daerah tidak seperti sistem bikameral di negara lain. The difference, for example, for United States, Bosnia, Herzegovina, approval of the second chamber of the law is required (their assent to legislation is required) and cannot be overridden, in contrast to Algeria neither chamber is fully involved, in contrast to Ireland and France whose veto may be overridden by the first chamber, while Australia and Spain are the absolute majority for the second chamber. ${ }^{12}$ Pada system di Amerika Serikat strong bicameralism dengan keseimbangan antara house of representative dan senate. ${ }^{13}$ Struktur Dewan Perwakilan Daerah dan Dewan Perwakilan Rakyat dalam tubuh Majelis Permusyawaratan Rakyat inilah yang merupakan ciri khas Indonesia sehingga bukan bikameral murni tetapi sistem lain yang merupakan ciri khas perwakilan di Indonesia. Kenyataannya Dewan Perwakilan Daerah hanya diberikan kewenangan pembahasan dalam hal fungsi kedaerahan atau rancangan yang berkaitan dengan kedaerahan. Pelaksanaannya dalam proses pembuatan rancangan undang-undang pun hanya diberikan kewenangan untuk mengajukan rancangan undang-undang terkait dengan kedaerahan, membahas dan memberikan pertimbangan tetapi tidak ikut mengesahkan rancangan undang-undang

9 H.R. Daeng Naja, Dewan Perwakilan Daerah Bikameral Setengah Hati, (Yogyakarta, Media Pressindo, 2004). hlm. 16.

10 Denny Indrayana, Negara Antara Ada dan Tiada ReformasiHukum Ketatanegaraan, (Jakarta, Kompas Media Nusantara, 2008). hlm. 14.

11 Enny Nurbaningsih, Implikasi Putusan Mahkamah Konstitusi Nomor 92/PUU-X/2012 dan Alternatif Model Hubungan Kelembagaan Terkait Pembentukan Undang-Undang, Jurnal Mimbar Hukum Volume 27, Nomor 1,( Februari 2015). hlm. 12

12 John Coakley, The Stare Revival of Bicameralism, The Journal of Legislative Studies, Volume 20, Number 4. (July 2014). pp. 542-572.

13 Hezron Sabar Royua Tinambunan dan Dicky Eko Prasetio, Rekonstruksi Konstitusi Dalam Regional Representative Dewan Perwakilan Daerah Terhadap Fungsi Legislatif, Masalah- Masalah Hukum Jilid 48, Number 3, (Juli 2019). hlm. 266-274. 
meskipun itu hal yang berkenaan dengan kedaerahan. Identiknya Dewan Perwakilan Daerah jika dipandang pada ranah konseptual yang mencirikan kedaerahan dapat disebut second chamber, hal ini seperti pendapat bahwa ... theoriticians of bicameralism saw the second house as the proper place for local or professional interest to participate in legislative and parliamentary work. ${ }^{14}$ Kondisi seperti ini dapat mengakibatkan tidak konsistennya norma yang telah disepakati. Hal ini dapat terjadi bila terdapat perbedaan pendapat antara dua lembaga legislatif yaitu Dewan Perwakilan Rakyat dan Dewan Perwakilan Daerah. Memang Dewan Perwakilan Daerah diberikan wewenang berkaitan pembuatan rancangan undangundang yang bersifat kedaerahan tetapi kewenangan itu seperti setengah hati dan apabila ada kontra maka Dewan Perwakilan Daerah tidak memiliki kewenangan untuk mengupayakan.

Syarat calon Dewan Perwakilan Daerah menurut Undang-Undang Republik Indonesia Nomor 7 Tahun 2017 tentang Pemilihan Umum terdapat beberapa ketentuan. Ketentuan syarat calon anggota Dewan Perwakilan Daerah antara lain pada Bagian Ketiga tentang Peserta Pemilu Dewan Perwakilan Daerah Pasal 182 Huruf 1 Undang-Undang Republik Indonesia Nomor 7 Tahun 2017 tentang Pemilihan
Umum. Pasal 182 Huruf I Undang-Undang Republik Indonesia Nomor 7 Tahun 2017 tentang Pemilihan Umum bahwa Perseorangan yang dapat menjadi peserta Pemilihan Umum salah satunya yaitu pada Huruf I bersedia untuk tidak berpraktik sebagai akuntan publik, advokat, notaris, pejabat pembuat akta tanah, dan/ atau tidak melakukan pekerjaan penyedia barang dan jasa yang berhubungan dengan keuangan negara serta pekerjaan lain yang dapat menimbulkan konflik kepentingan dengan tugas, wewenang, dan hak sebagai anggota Dewan Perwakilan Daerah sesuai dengan ketentuan peraturan perundangundangan. ${ }^{15}$ Eksistensi undang-undang ini sebenarnya untuk menjaga netralitas lembaga Dewan Perwakilan Daerah agar esensi aspirasi yang dibawa itu adalah murni asensi masyarakat bukan aspirasi yang tercampur dengan muatan kepentingan tertentu karena menjabat atau menduduki posisi tertentu selain sebagai Dewan Perwakilan Daerah.

Lembaga Legislatif diantaranya ada Dewan Perwakilan Rakyat dan Dewan Perwakilan Daerah di Indonesia adalah sebagai penyeimbang eksistensi pembentukan peraturan oleh eksekutifagar dalam pembuatan peraturan perundang-undangan tidak hanya memuat kepentingan eksekutif tetapi juga sarat muatan legislatif yang merupakan wakil dari masyarakat yang diharapkan suatu

14 Miguel Herrero de Miñón, The Passing of Bicameralism, The American Journal of Comparative Law, Volume 23, Number 2 (Spring 1975), pp. 236-254. Published by: American Society of Comparative Law is collaborating with JSTOR to digitize, preserve and extend access to The American Journal of Comparative Law.

15 Undang-Undang Republik Indonesia Nomor 7 Tahun 2017 tentang Pemilihan Umum Lembaran Negara Republik Indonesia Tahun 2017 Nomor 182 dan Tambahan Lembaran Negara Republik Indonesia Nomor 6109 
peraturan juga memenuhi apa yang menjadi kebutuhan masyarakat.

Perlu diketahui dalam teori pembuatan peraturan perundang-undangan khususnya undang-undang sebagai produk hukum semestinya tidak hanya sebagai kontrol sosial masyarakat tetapijuga kontrol terhadap produk hukum sebelum peraturan itu diberlakukan. Teori norma hukum (pembuatan hukum) dan teori negara hukum bahwa hakikat hukum adalah melindungi masyarakat yang awalnya timbul karena adanya teori negara sebagai penjaga malam. Teori ini berlaku kemudian timbul pemerintah mengatur masyarakat (kehendak masyarakat agar negara dapat melindungi masyarakat) pada akhirnya timbul teori bahwa produk hukum yang dibuat pemerintah/penguasa diperlukan adanya aspirasi masyarakat agar tidak timbul absolutisme bahkan abuse of power.

Rangkaian penjelasan teori tersebut menggambarkan betapa pentingnya suatu produk hukum yang benar-benar bermuatan keadilan, kemanfaatan, dan kepastian yang akan terjadi bila hukum benar-benar bermuatan apa yang dicitakan dan tidak terpolusi oleh kepentingan tertentu. Upaya netralitas fungsi Dewan Perwakilan Daerah ini sudah tertera pahda konstutusi dengan memisahkan kewenangan antara Dewan Perwakilan Daerah dengan Dewan Perwakilan Rakyat serta diperkuat dengan adanya Putusan Mahkamah Konstitusi Republik Indonesia Nomor 30/PUU-XVI/2018.

Mahkamah Konstitusi mengeluarkan Putusan Nomor 30/PUU-XVI/2018 yang memberikan penguatan atas netralitas Dewan Perwakilan Daerah. Putusan Mahkamah Konstitusi Nomor 30/PUU-XVI/2018 ini memiliki konsekuensi hukum terhadap Pasal 182 Huruf I Undang-Undang Republik Indonesia Nomor 7 Tahun 2017 tentag Pemilihan Umum. Pada intinya putusan Mahkamah Konstitusi Republik Indonesia Nomor 30/PUU-XVI/2018 tersebut berkaitan dengan syarat bagi perseorangan untuk menjadi calon anggota Dewan Perwakilan Daerah. Menurut permohonan yang diajukan pada Mahkamah Konstitusi bahwa anggota dewan Perwakilan Daerah bersedia untuk tidak berpraktik di posisi tertentu serta dalam pekerjaan lain. Frasa posisi tertentu dan pekerjaan lain ini dikhawatirkan akan berdampak pada eksistensi netralitas suatu lembaga Dewan Perwakilan Daerah. Posisi tertentu serta pekerjaan lain ini dapat berdapak menimbulkan persoalan ketika anggota menjalankan tugas, fungsi, dan wewenangnya maupun kewajiban dan haknya sebagai anggota Dewan Perwakilan Daerah yang pada akhirnya ketika berkaitan dengan fungsi legislasi bukan murni aspirasi masyarakat yang diusung tetapi aspirasi yang sudah bermuatan kepentingan tertentu yang akhirnya masuk dalam norma-norma yang akan menjadi bakal rancangan produk hukum yang akan dihasilkan.

Mahkamah Konstitusi memberikan makna terhadap frasa "pekerjaan lain" dipertegas dengan dimasukkannya frasa partai politik yaitu frasa sebagai pengurus 
partai politik sehingga pengurus partai politik masuk dalam lingkup pekerjaan lain. Hal ini Mahkamah Konstitusi melakukan perluasan bahkan konkritisasi terhadap frasa pekerjaan lain yang pada awalnya dalam ketentuan Pasal 182 huruf I Undang-Undang Republik Indonesia Nomor 7 Tahun 2017 tentang Pemilihan Umum frasa pekerjaan lain itu bersifat umum (hanya menyebut pekerjaan lain dan tidak dipertegas) dan tidak disebutkan secara konkrit (seperti penyebutan pengurus partai politik). Pemaknaan terhadap frasa pekerjaan lain menjadi mempersempit lingkup kandidat yang akan mencalonkan sebagai anggota Dewan Perwakilan Rakyat. Tentu saja Putusan Mahkamah Konstitusi ini membawa konsekuensi terhadap norma dalam Undang-Undang Pemilihan Umum. Konsekuensi yuridis Putusan Mahkamah Konstitusi Republik Indonesia Pasal 182 huruf I Undang-Undang Republik Indonesia Nomor 7 Tahun 2017 tentang Pemilihan Umum yaitu perseorangan yang merupakan pengurus partai politik tidak dapat mengajukan sebagai kandidat bakal calon anggota Dewan Perwakilan Daerah kalau pun ingin mengajukan maka kandidat yang bersangkutan harus melepaskan jabatannya sebagai pengurus partai politik.

Pada akhirnya untuk memberi makna terhadap frasa pekerjaan lain hanya pada Pasal 182 huruf I Undang-Undang Republik Indonesia Nomor 7 Tahun 2017 tentang Pemilihan Umum tanpa melihat
Putusan Mahkamah Konstitusi Republik Indonesia Nomor 30/PUU-XVI/2018 terjadi inkonstitusional. Oleh karenanya, pemaknaan terhadap frasa pekarjaan lain tentu harus melihat Putusan Mahkamah Konstitusi Republik Indonesia Nomor 30/ PUU-XVI/2018 yang mencakup sebagai pengurus partai politik sehingga norma yang diterapkan menjadi konstitusional. Frasa pekerjaan lain dalam Pasal 182 huruf I Undang-Undang Republik Indonesia Nomor 7 Tahun 2017 tentang Pemilihan Umum (Lembaran Negara Republik Indonesia Tahun 2017 Nomor 182, Tambahan Lembaran Negara Republik Indonesia Nomor 6109) bertentangan dengan konstitusi dan tidak mempunyai kekuatan hukum mengikat secara bersyarat sepanjang tidak dimaknai mencakup pula pengurus (fungsionaris) partai politik. ${ }^{16}$ Hal ini menjadikan penormaan dalam undangundang menjadi berubah meskipun hanya dalam hal pemaknaan saja tetapi berdampak besar dalam konsistensi Mahkamah Konstitusi dalam menjaga amanah konstitusi memurnikan fungsi Dewan Perwakian Daerah.

Mahkamah Konstitusi dengan Putusannya itu justru mempertahankan konsistensi lembaga Dewan Perwakilan Daerah dalam konstitusi Undang-Undang Dasar Negara Republik Indonesia Tahun 1945. Hal ini berkaitan dengan fungsi bikameral yang ada di Indonesia walaupun terapan atas bikameral itu masih bersifat soft bikameral khas Indonesia yang berbeda dengan negara lain. 
Dua kamar parlemen yang terdiri dari Dewan Perwakilan Rakyat dan Dewan Perwakilan Daerah dengan memaknai fungsi dalam konstitusi yang pada akhirnya fungsi itu tidak sama antara Dewan Perwakilan Rakyat maupun dengan Dewan Perwakilan Daerah sehingga Dewan Perwakilan Daerah disebut sebagai kamar kedua. Putusan Mahkamah Konstitusi Republik Indonesia Nomor 30/ PUU-XVI/2018 ini semakin menguatkan Dewan Perwakilan Daerah sebagai lembaga legislatif pembawa amanah daerah sehingga Putusan Mahkamah Konstitusi Republik Indonesia Nomor 30/PUU-XVI/2018 menambah perbaikan pada kamar kedua dalam fungsi parlemen. Jika dilihat dari peran ini maka Mahkamah Konstitusi berhasil mempertahankan eksistensi Dewan Perwakilan Daerah dalam konstitusi.

Mahkamah Konstitusi dengan Putusan Mahkamah Konstitusi Republik Indonesia Nomor 30/PUU-XVI/2018 dianggap mempertahankan lembaga Dewan Perwakilan Daerah dalam konstitusi karena pengenaan frasa pengurus partai politik membawa konsekuensi bahwa pengurus partai politik tidak dapat mendaftar bahkan mencalonkan menjadi anggota Dewan Perwakilan Daerah sehingga tidak dapat masuk dalam tubuh Dewan Perwakilan Daerah. Sikap Mahkamah Konstitusi ini menjadikan lembaga Dewan Perwakilan Daerah tidak bersinggungan dengan parti politik dan diharapkan tidak menimbulkan konflik berkepentingan sehingga terjadi pemurnian tubuh Dewan Perwakilan Daerah agar benar-benar membawa aspirasi dan kebutuhan daerah tanpa dicampuri hiruk pikuk urusan partai politik yang mengakibatkan persoalanpersoalan tertentu yang mengenyampingkan fungsi sebenarnya sebagai anggota Dewan Perwakilan Daerah.

Eksistensi fungsi lembaga Dewan Perwakilan Daerah sesuai dengan konstitusi adalah penting. Pertama, harmonisasi peraturan perundang-undangan dengan pengutan makna norma demi kepastian hukum. Harmonisasi hukum merupakan upaya merealisasi keselarasan, kesesuaian, keserasian, kecocokan, keseimbangan antara norma hukum dalam peraturan perundangundangan sebagai system hukum (kesatuan kerangka system hukum nasional). ${ }^{17}$ Hal ini untuk mengatasi perbedaan, pertentangan dan kejanggalan diantara norma hukum dalam peraturan sebagai system. ${ }^{18}$ Indonesia adalah negara hukum dan peraturan perundangundangan sebagai sumber hukumnya serta sumber hukum paling tinggi dalam hierarki peraturan perundang-undangan sesuai Pasal 7 ayat (1) Undang-Undang Republik Indonesia Nomor 12 Tahun 2011 tentang Pembentukan Peraturan Perundang-Undangan adalah konstitusi yaitu Undang-Undang Dasar

17 Kusnu Goesniadhie Slamet, Harmonisasi Hukum dalam Perspektif Perundang-undangan, Jurnal Hukum Volume 11, Nomor 27, (September 2004). hlm. 82-96.

18 Sapto Budoyo, Konsep Langkah Sistemik Harmonisasi Hukum dalam Pembentukan Peraturan Perundangundangan, Jurnal Ilmiah CIVIS Volume IV, Nomor 2, (Juli 2014). hlm. 607-622. 
Negara Republik Indonesia Tahun $1945 .{ }^{19}$ Oleh karenanya penting adanya harmonisasi hukum dan konstitusi sebagai dasarnya maka penting undang-undang berdasar pada konstitusi. Hal ini berkaitan dengan keberlakuan yuridis. Adanya parameter sebuah peraturan perundang-undangan dapat berlaku dengan baik yaitu dasar keberlakuan yuridis, sosiologis, filosofis. Unsur yang terdapat pada keberlakuan yuridis salah satunya adalah keharusan tidak bertentangan dengan peraturan perundang-undangan yang lebih tinggi tingkatannya dan diperkuat dengan pendapat Soerjono Soekanto dan Purnadi Purbacara diilhami dari pendapat Hans Kelsen bahwa setiap kaidah hukum harus berdasarkan kaidah yang lebih tinggi tingkatannya. ${ }^{20} \quad$ Konstitusi memaknai lembaga Dewan Perwakilan Daerah dengan menormakan fungsinya ke dalam pasal-pasal konstitusi. Dewan Perwakilan Daerah diatur dalam konstitusi yang mana berbeda dengan norma dalam konstitusi yang mengatur Dewan Perwakilan Rakyat. Konstitusi, Bab VIIB Amandemen Ketiga tentang Pemilihan Umum membedakan peserta pemilihan umum antara Dewan Perwakilan Daerah dan Dewan Perwakilan Rakyat. Pembeda itu diatur dalam Pasal 22 E Undang-Undang Negara Republik Indonesia Tahun 1945 bahwa pada ayat (4) bahwa Peserta pemilihan umum untuk memilih anggota Dewan Perwakilan Daerah adalah perseorangan, hal ini berbeda dengan Dewan Perwakilan Rakyat. Peserta pada Dewan Perwakilan Rakyat diatur pada ayat (3) bahwa peserta pemilihan umum untuk memilih anggota Dewan Perwakilan Rakyat dan anggota Dewan Perwakilan Rakyat Daerah adalah partai politik, disinilah pembedanya. Ketentuan ayat (3) terdapat frasa partai politik sehingga peserta bagi anggota Dewan Perwakilan Rakyat diisi dari person-person partai politik sedangkan pada ayat (4) tidak terdapat frasa partai politik bahkan disebutkan pada ayat (4) itu bahwa yang menjadi peserta Dewan Perwakilan Daerah adalah dari perseorangan. Penormaan perseorangan pada ketentuan konstitusi tanpa frasa partai politik ini membuktikan bahwa perseorangan yang dimaksut adalah betulbetul independen atau mandiri atau berdiri sendiri maksudnya bebas atau tidak ada campur tangan partai politik. Ketentuan tersebut dapat disimpulkan memang terdapat pembeda bukan hanya artifisial bahkan memang dibedakan peserta pemilihan umum antara Dewan Perwakilan Daerah dengan Dewan Perwakilan Rakyat dengan struktur ayat yang berbeda. Norma konstitusi telah membedakan demikian kemudian terdapat Undang-Undang Pemilu dan ditegaskan kembali oleh Putusan Mahkamah Konstitusi. Oleh karena itu, benar

19 Undang-Undang Republik Indonesia Nomor 12 Tahun 2011 tentang Pembentukan Peraturan Perundangundangan. Lembaran Negara Republik Indonesia Tahn 2011 Nomr 82. Tambahan Lembaran Negara Republik Indonesia Nomor 6109.

20 Sirajuddin, dkk, Legislatiive Drafting, Pelembagaan Metode Partisipatif dalam Pembentukan Peraturan Perungdang-undangan, (Malang: Setara Press, 2016), hlm. 23. Lihat juga Bagir Manan, Dasar-Dasar Perundang-undangan Indonesia, (Jakarta: IN-HILL-CO, 1992). hlm. 7. 
bahwa Putusan Mahkamah Konstitusi ini menegaskan dan menguatkan penormaan dalam konstitusi.

Kedua, adanya pemenuhan aspirasi masyarakat dan kebutuhan atau aspirasi daerah. Produk hukum pemerintah dalam hal ini peraturan perundang-undangan khususnya Undang-Undang memiliki materi muatan yang lebih umum dibandingkan dengan peraturan perundang-undangan lainnya di bawah undang-undang bahkan dikehendaki berdaya laku dan guna khususnya di ranah nasional. Salah satu materi muatan yang dinormakan dengan wadah undang-undang adalah adanya hal-hal yang berkaitan dengan kepentingan orang banyak atau kewajiban masyarakat luas. Suatu penormaan begrkaitan dengan masyarakat luas maka tentunya aspirasi yang masuk bukan saja aspirasi kehendak pemerintah tetapi juga aspirasi masyarakat terlebih penting lagi adalah aspirasi daerah yang mengakomodasi kebutuhan-kebutuhan dan kepentingan daerah. Dewan Perwakilan Rakyat merupakan political representation dan Dewan Perwakilan Daerah merupakan territorial representation. Oleh karena itu, inilah fungsi Dewan Perwakilan Daerah sesuai dengan Pasal 22 D Undang-Undang Dasar Negara Republik Indonesia Tahun 1945 yang mengatur bahwa rancangan undang-undang yang diusulkan atau berasal dari Dewan Perwakilan Daerah adalah rancangan Undangundang yang berkaitan dengan kedaerahan. Intinya suatu pengaturan berkaitan dengan undang-undang maka semakin banyak aspirasi yang dikumpulkan maka akan semakin mengakomodir kepentingan masyarakat maupun daerah. Pemisahan keduanya adalah penting, misalnya Dewan Perwakilan Rakyat mengusung aspirasi rakyat lewat partai politik sedangkan Dewan Perwakilan Daerah mengakomodasi kepentingan daerah. Dewan Perwakilan Daerah diisi oleh perorangan diharapkan yang mengerti kebutuhan dan kepentingan daerahnya dan tidak tercampur dengan kepentingan politik sehingga murni apa yang diusung adalah kepentingan daerah. Maksudnya, Dewan Perwakilan Rakyat merupakan penampung aspirasi dari masyarakat sedangkan Dewan Perwakilan Daerah penampung aspurasi kebutuhan daerah, keduanya memiliki titik temu pada saat pembahasan pembentukan peraturan perundang-undangan. Kedua lembaga legislatif tersebut apabila masing masing mewakili aspirasi yang telah ditentukan maka peraturan yang dibentuk semakin banyak menampung aspirasi dari masyarakat maupun daerah. Berkaitan dengan prinsip otonomi atau prinsip pembagian daerah yang tertera pada Pasal $1^{21}$ Undang-Undang Dasar Negara Republik Indonesia Tahun 1945 maka dibutuhkan kandidat yang betul-betul mengerti kepentingan daerah dan aspirasi itu penting untuk diteruskan pada tingkat pemerintah pusat dalam hal ini diwujudkan dalam menjalankan fungsinya sebagai anggota Dewan Perwakilan Daerah. Kepentingan yang

21 Pasal 18 Undang-Undang Dasar Negara Republik Indonesia Tahun 1945 (setelah Amandemen). 
diusung oleh Dewan Perwakilan Rakyat dan Dewan Perwakilan Daerah berasal dari faktor yang berbeda sehingga diharapkan lebih dapat melengkapi aspirasi dalam merancang undang-undang sehingga rancangan undangundang yang nantinya disahkan dan berlaku lebih mengakomodasi kepentingan seluruh masyarakat. Aspirasi kedaerahan dapat dimasukkan walaupun pada kenyataannya terdapat ketimpangan karena Dewan Perwakilan Daerah hanya mengusulkan, membahas dan mengawasi saja dan tidak ikut serta dalam pengesahan maupun persetujuan itu pun ketika mengusulkan melewati Dewan Perwakilan Rakyat. Fajrul, Ketimpangan makin mencolok karena Presiden dilibatkan sebagai pembahas dan pengambil keputusan bersama Dewan Perwakilan Rakyat sedangkan Dewan perwakilan Rakyat dipinggirkan, pola hubungan ini boleh disebut tipe hibrida. ${ }^{22}$ Terdapat teori mengatakan hukum selalu tertinggal dengan peristiwa yang terjadi di masyarakat, oleh karena itu hukum harus dinamis sehingga dapat mengikuti perkembangan masyarakat. Upaya pemurnian eksistensi aspirasi Dewan Perwakilan Daerah ini diharapkan menambah lengkapnya aspirasi yang tertampung dalam rancangan undang-undang. Rancangan undang-undang tersebut yang kemudian menjadi UndangUndang sehingga Undang-undang mampu mengakomodasi seluruh kepentingan masyarakat dan daerah sehingga political representation dan territorial representation terpenuhi. Konsep ini setidaknya terdapat aspirasi masyarakat walaupun tidak secara langsung agar undang-undang yang dihasilkan relevan dengan kebutuhan dan permasalahan masyarakat.

Ketiga, teori pemisahan dan pembagian kekuasaan diperlukan cheks and balances. Adanya pemisahan kekuasaan antara eksekutif, legislatif, dan yudikatif serta adanya pembagian kewenangan tentu diperlukan suatu evaluasi sehingga dapat saling menilai. Begitu juga pada lembaga legislatif perlu adanya checks and balances di dalamnya. Dewan Perwakilan Rakyat dan Dewan Perwakilan Daerah perlu adanya suatu evaluasai saling menilai dengan checks and balances yang dapat dilakukan apabila terjadi kompetisi satu sama lain. Hal ini sesuai dengan pembedaan asal anggota pada Dewan Perwakilan Rakyat maupun Dewan Perwakilan Daerah. Dewan Perwakilan Rakyat berasal dari partai politik dan Dewan Perwakilan Daerah berasal dari perseorangan (daerah) sehingga muncul persaingan. Berbeda apabila Dewan Perwakilan Rakyat dengan Dewan Perwakilan Daerah sama-sama berasal dari partai politik maka dikhawatirkan persaingan yang melahirkan evaluasi itu berkurang. Apalagi berasal dari partai yang sama pasti fungsi checks and balances tadi

22 Mohammad Fajrul Falaakh, Pertumbuhan dan Model Konstitusi Serta Perubahan Undang-Undang Dasar 1945 oleh Presiden, Dewan Pehrwakilan Rakyat, Dan Mahkamah Konstitusi (The Growth, Model, and Informal Changes of An Indonesia Constitusion), (Yogyakarta: Gadjah Mada University Press, 2014). hlm. 91. Dimaksud tipe hibrida yaitu proses legislasi tiga kamar (three-chamber legislative process) yang pengambilan keutusannya di tangan Dewan Perwakilan Rakyat dan Presiden (president-executive in parliament). 
tidak berjalan maksimal atau justru menurun.

Keempat, terjadinya perwakilan ganda dalam lembaga perwakilan. Berkenaan dengan pembuatan peraturan perundang-undangan (Undang-undang) yang terjadi adalah adanya perwakian ganda misalnya ketika pembuatan Undang-Undang yang bersifat kedaerahan ketika terdapat suara pada Dewan Perwakilan Rakyat maka dimungkinkan terdapat suara di Dewan Perwakilan Daerah sebab partai yang sama sehingga terdapat suara partai A pada Dewan Perwakilan Rakyat dan terdapat pula suara partai A pada Dewan Perwakilan Daerah. Hal ini kemungkinan terjadi pula pada saat pembuatan atau perubahan produk hukum yang lebih tinggi lagi. Bab XVI tentang Perubahan Undang-Undang Dasar Pasal 37 Undang-Undang Dasar Negara Republik Indonesia Tahun 1945 bahwa perubahan dilakukan oleh Majelis Permusyawaratan Rakyat yang di dalamnya terdapat anggota Dewan Perwakilan Rakyat dan Dewan Perwakilan Daerah inilah yang kemudian berpotensi adanya suara atau keputusan atau keterwakilan ganda karena partai politik yang sama. Adanya Putusan Mahkamah Konstitusi Republik Indonesia Nomor 30/ PUU-XVI/2018 membawa konsekuensi tidak adanya distorsi yang menyebabkan double representation partai politik ketika mengamnbil keputusan dalam menjalankan fungsinya.
Kelima, Konsistensi pada putusan Mahkamah Kontitusi mencerminkan konsistensi lembaga Mahkamah Konstitusi. Putusan Mahkamah Konstitusi Republik Indonesia Nomor 30/PUU-XVI/2018 terdapat kesesuaian dengan putusan Mahkamah Konstitusi sebelumnya. Kesesuaian ini mencerminkan konsistensi yang sama putusan mahkamah konstitusi yaitu dengan Putusan Mahkamah Konstitusi Republik Indonesia Nomor 10/PUU-VI/2008 berkaitan dengan keanggotaan atau partai politik yang ikut pemilihan umum, Putusan Mahkamah Konstitusi Republik Indonesia Nomor 92/ PUU-X/2012 tentang kewenangan Dewan Perwakilan Daerah, dan Putusan Mahkamah Konstitusi Republik Indonesia Nomor 73/ PUU-XII/2014.

Putusan Mahkamah Konstitusi yang isinya mengabulkan pemohon, harus menjadi bahan rujukan bagi perancang undang-undang agar tidak melakukan kesalahan yang sama melalui penlaian berbasis politik (political judgment). ${ }^{23}$ Oleh karenanya putusan mahkamah koshtitusi harus menghilhami lembaga legislatif dalam membuat produk hukum khususnya undang-undang. Hal ini dikarenakan penafsiran yang dilakukan oleh Mahkamah Konstitusi wajib ditaati karena Mahkamah Konstitusi sebagai penafsir tunggal norma dalam Undang-Undang Dasar Negara Republik Indonesia Tahun 1945. Penilaian

23 Himawan Estu Bagijo, Negara Hukum dan Mahkamah Konstitusi: Perwujudan Negaa Hukum yang Demokratis Melalui Wewenang Maahkamah Konstitusi dalam Pengujian Undang-Undang, (Yogyakarta: Laksbang Grafika, 2013). hlm. 40. 
sebagai penafsir Konstitusi oleh Mahkamah Konstitusi menjadi penguat batasan atas keluasaan pembentuk peraturan dalam membentuk peraturan perundang-undangan yang mengindikasikan pertentangan dengan konstitusi, detournement de pouvoir bahkan willekeur karena pada dasarnya konstitusi membatasi kekuasaan agar tidak terjadi penyimpangan. Meskipun suatu undangundang dinilai buruk, Mahkamah Konstitusi tidak dapat membatalkan kecuali produk legal policy tersebut melanggar dan tak sesuai tujuan negara dalam konstitusi, pancasila dan norma konstitusi yang merupakan aspek penilaian Mahkamah Konstitusi dalam menafsir konstitusi. ${ }^{24}$ Perorangan, Badan Hukum, maupun institusi tidak dapat dikenakan pelanggaran hukum karena melakukan apa yang diwenangkan dalam Putusan Mahkamah Konstitusi. Putusan mahkamah konstitusi wajib menjadi dasar dalam tafsiran atau pemaknaan suatu norma. Lembaga legislatif ketika melakukan perubahan atau pembuatan peraturan perundang-undangan yang baru dipengaruhi oleh putuan mahkamah konstitusi. Kathleen Barret, pengaruh de facto Mahkamah Konstitusi atas lembaga legislatif yaitu lembaga legislatif melakukan perubahan undang-undang untuk menyesuaikan dengan putusan Mahkamah Konstitusi. ${ }^{25}$
Putusan Mahkamah Konstitusi mempengaruhi produk hukum lembaga legislatif dan mempengaruhi legal action pada lembaga pelaksana dalam hal ini adalah Komisi Pemilihan Umum. Komisi Pemilihan Umum pun harus mematuhi Putusan Mahkamah Konstitusi. Hal ini dikarenakan Putusan Mahkamah Konstitusi bersifat final seperti pada Undang-Undang Dasar Negara Republik Indonesia Tahun 1945 bahwa Mahkamah Konstitusi ... yang putusannya bersifat final ... pada Pasal $24 \mathrm{C}$ ayat (1) yang mengatur tentang kewenangan Mahkamah Konstitusi. Konstitusi menegaskan bahwa putusan Mahkamah Konstitusi bersifat erga omnes dan karena tidak ada upaya lain karena merupakan pengadilan tingkat pertama dan terakhir maka putusan itu in kracht van gewijsde dan resjudicata pro veritate habetur. ${ }^{26}$ Hal ini membawa konsekuensi yuridis bahwa putusan tidak hanya mengikat inter parties tetapi juga erga omnes karena sifat hukumnya yang publik dan terdapat kelemahan atas pelaksanaan sebab peran Mahkamah Konstitusi sebagai negative legislature, tiada enforcement agencies, tiada tenggang waktu implementasi dan tidak ada konsekuensi yuridis terhadap pengabaian. ${ }^{27}$ Putusan yang bersifat deklaratif juga memiliki

24 Radita Ajie, Batasan Pilihan Kebijakan Pemnbentuk Undang-kundang (Open Legal Policy) dalam Pembentukan Peraturan Perundang-undangan Berdasarkan Tafsir Putusan Mahkamah Konstitusi (Limit To Open Legal Policy In Legislation Making Based on Constitutional Court Decision), Jurnal Legislasi Indonesia Volume 13, Nomor 02 (Juni 2016). hlm. 111-120.

25 Kathleen Barrett, Constitutional Courts, Legislative Autonomy, and Democracy: What Price Rights? Political Science Dissertations Department of Political Science, (Georgia: Georgia State University, 2014). hlm. 144116.

26 Fajar Laksono Soeroso, Aspek Keadilan dalam Sifat Final Putusan Mahkamah Konstitusi, Jurnal Konstitusi ,Volume 11, Nomor 1, (Maret 2014). hlm. 64-84

27 Fadzlun Budi Sulistyo Nugroho, Sifat Keberlakuan Asas Erga Omnes dan Implementasi Putusan Mahkamah Konstitusi, Jurnal Gorontalo Law Review Volume 2, Nomor 2, (Oktober 2019). hlm. 95-104. 
sifat konstitutif yang membutuhkan kejelasan implementasinya agar efektif berdasar checks and balances. $^{28}$ Konsekuensinya kandidat peserta calon Pemilihan Umum pada Dewan Perwakilan Daerah memiliki dua pilihan yaitu melepaskan jabatannya dari pengurus partai politik atau batal mencalonkan pada peserta pemilihan umum anggota Dewan Perwakilan Daerah.

Putusan Mahkamah Konstitusi ini manjadi lebih pelik ketika ingin dilakukan pelaksanaannya oleh Komisi Pemilihan Umum karena dikeluarkan Putusan Pengadilan Tata Usaha Negara yang mengabulkan gugatan yang dilakukan oleh kuasa hukum Oesman Sapta terkait dengan Keputusan Komisi Pemilihan Umum Nomor 1130/PL.01.4-Kpt/06/KPU-IX/2018 tanggal 20 September 2018 tentang Penetapan Daftar Calon Tetap Perseorangan Peserta Pemilihan Umum Anggota Dewan Perwakilan Daerah Tahun 2019. ${ }^{29}$ Putusan Pengadilan Tata Usaha ini membatalkan Surat Keputusan Komisi Pemilihan Umum terkait dengan Daftar Calon tetap Dewan Perwakilan Daerah dan membuat Surat Keputusan baru memasukkan Oesman yang sebelumnya tidak masuk daftar karena Peraturan Komisi Pemilihan Umum Nomor 24 Tahun 2018 (pengurus partai politik mengundurkan diri sebelum masuk daftar calon). Peraturan Komisi Pemilihan Umum Nomor 24 Tahun 2018 merupakan kelanjutan dari Putusan Mahkamah Konstitusi Nomor 10/PUU-IV/2018 atas uji materi UndangUndang Republik Indonesia Nomor 7 Tahun 2017 tentang Pemilihan Umum (pengurus partai pilitik tidak boleh mencalonkan Dewan Perwakilan Daerah). Komisi Pemilihan Umum dianggap mengabaikan putusan Pengadilan Tata Usaha Negara jika melaksanakan Putusan Mahkamah Konstitusi yang berbeda pandangan dengan putusan Pengadilan Tata Usaha Negara. Sebelum dilkeluarkan Putusan Pengadilan Tata Usaha Negara, Putusan Mahkamah Agung bahwa melarang pengurus partai politik mengikuti kompetisi calon legislatif pada Dewan Perwakilan Daerah pada pemilihan umum selanjutnya (yaitu setelah Pemilihan Umum Tahun 2019). ${ }^{30}$

Sebenarnya Putusan Mahkamah Konstitusi merupakan bentuk penafsiran terhadap konstitusi dan merupakan lembaga satusatunya dalam menafsirkan konstitusi dan merupakan wenang yang diberikan oleh Pasal 24C ayat (1) Undang-Undang Dasar Negara Republik Indonesia Tahun 1945. Putusan Hakim Mahkamah Konstitusi merupakan hasil upaya penafsiran konstitusi dengan original intent theory maupun original meaning theory. ${ }^{31}$ Komisi pemilihan Umum ketika

28 Maruarar Siahaan, Peran Mahkamah Konstitusi dalam Penegakan Hukum Konstitusi, Jurnal Hukum Volume 16, Nomor 3, (Juli 2009). hlm. 357-378.

29 Keputusan Komisi Pemilihan Umum Nomor 1130/PL.01.4-Kpt/06/KPU-IX/2018 tanggal 20 September 2018 tentang Penetapan Daftar Calon Tetap Perseorangan Peserta Pemilihan Umum Anggota Dewan Perwakilan Daerah Tahun 2019.

30 Putusan Mahkamah Agung Republik Indonesia Nomor 65 P/HUM/2018, tertanggal 25 Oktober 2018.

31 Mohammad Agus Maulidi, Problematika Hukum Implementasi Putusan Final dan Mengikat Mahkamah Konstitusi Perspektif Negara Hukum, Jurnal Hukum Ius Quia Iustum Volume 24, Issue 4, (Oktober 2017) hlm. 535-557. 
menjalankan Putusan Mahamah Konstitusi berarti menjalankan perintah konstitusi oleh karena itu tidak perlu dikhawatirkan tentang putusan Pengadilan Tata Usaha Negara yang tidak sejalan dengan konstitusi. Putusan Pengadilan Tata Usaha Negara sebenarnya mendasarkan perkara berdasarkan Peraturan Komisi Pemilihan Umum, sedangkan putusan Mahkamah Konstitusi yang menafsirkan konstitusi adalah atas analisis terhadap konstitusi. Artinya, kedudukaan pada norma hukum adalah lebih tinggi sehingga Komisi Pemilihan Umum tidak perlu khawatir dalam melaksanakan Putusan Mahkamah Konstitusi. Dewan Perwakilan Rakyat pada akhirnya akan kembali pada hakikatnya sehingga poduk hukum yang dihasilkan akan lebih memiliki keadilan, kemanfaatan, dan kepastian serta memenuhi semua kebutuhan masyarakat maupun daerah serta hukum tetap tidak tertinggal dengan perkembangan masyarakat. Konsep ini bukan berarti posisi lembaga Mahkamah Konstitusi lebih tinggi dari Pengadilan Tata Usaha Negara tetapi sifat norma hukum yang dikenai norma. Putusan Peadilan Tata Usaha Negara ada dasarnya memiliki sifat final dan mengikat yang diputuskan lebih dulu dari pada Perkara yang diputuskan oleh Mahkamah Konstitusi sehingga Putusann Mahkamah Konstitusi justru dikalahkan dari pada putusann Pengadilan Tata Usaha Negara karena sifatfinal dari Pengadilan Tata Usaha Negara. Tetapi, aspirasi bersifat kedaerahan masih dapat dijaga apabila peserta yangg mencalonkan menjadi anggota Dewan Perwakilan Rakyat melepas jabatannya sebagai pengurus partai politik sehingga aspirasi yang dibawa harus benar-benar mewakili aspirasi masyarakat dan kepentingan daerah.

\section{Simpulan}

Pembuatan hukum mesti prospek masa depan yang dibuat untuk memenuhi atau menyelesaikan tantangan-tantangan hukum di masa depan. Norma hukum yang diberlakukan tidak hanya mencakup kepentingan pemerintah tetapi juga kepentingan masyarakat dan daerah. Pemaknaan norma konstitusi oleh Mahkamah Konstitusi dalam putusan Mahkamah Konstitusi (pemaknaan terhadap Pasal 182 (huruf I Undang-Undang Republik Indonesia Nomor 7 Tahun 2017 tentang Pemilihan Umum)) dapat diartikan pemaknaan kepada norma dasar karena dalam hierarki konstitusi norma paling dasar maka agar terjadi harmonisasi hukum maka diikuti atau menjadi dasar norma-norma di bawahnya. Oleh karena itu ketika Komisi Pemilihan Umum menjalankan Putusan Mahkamah Konstitusi maka ang terjadi adalah konstitusional. Secara konteks Putusan Pengadilan Tata Usaha Negara yang menjadi kebimbangan Komisi Pemilihan umum menjalankan fungsinya sebenarnya ketika terlihat dalam sistem norma bertentangan dengan konstitusi. Komisi Pemilihan Umum apabila melaksanakan apa yang di putuskan Mahkamah Konstitusi justru menegaskan pembeda kewenangan antara 
Dewan Pewakilan Daerah dengan Dewan benar-benar mencerminkan kebutuhan hukum Perwakilan Daerah. Dengan demikian produk di masa depan yang mencakup segala lingkup legislasi yang kemudian hari dihasilkan keghidupan bernegara yang tidak memihak meminimalkan konflik kepentingan pagda kepentingan tertentu maupun kelompok proses maupun pelaksanaan proses legislasi tertentu. sehingga prodek legislasi yang dihasilkan

\section{DAFTAR PUSTAKA}

\section{Buku}

Denny Indrayana, Negara Antara Ada dan Tiada Reformasi Hukum Ketatanegaraan, (Jakarta, Kompas Media Nusantara, 2008).

Geoffrey Brennan and Alan Haamlin, Democratic Devices and Desires, Theories of Institutional Design, (Cambridge, Cambridge University Press 2000).

Himawan Estu Bagijo, Negara Hukum dan Mahkamah Konstitusi: Perwujudan Negaa Hukum yang Demokratis Melalui Wewenang Mahkamah Konstitusi dalam Pengujian Undang-Undang, (Yogyakarta: Laksbang Grafika, 2013). H.R. Daeng Naja, Dewan Perwakilan Daerah Bikameral Setengah Hati, (Yogyakarta, Media Pressindo, 2004).

Kathleen Barrett, Constitutional Courts, Legislative Autonomy, and Democracy: What Price Rights? Political Science Dissertations Department of Political Science, (Georgiea: Georgia State University, 2014),
Margarito Kamis, Jalan Panjang Konstitusionalisme Indonesia, (Malang, Setara Press, 2014),

Mohammad Fajrul Falaakh, Pertumbuhan dan Model Konstitusi Serta Perubahan Undang-Undang Dasar 1945 oleh Presiden, Dewan Pehrwakilan Rakyat, Dan Mahkamah Konstitusi (The Growth, Model, and Informal Changes of An Indonesia Constitusion), (Yogyakarta: Gadjah Mada University Press, 2014), hlm. 91.

Sirajuddin, dkk, Legislatiive Drafting, Pelembagaan Metode Partisipatif dalam Pembentukan Peraturan Perungdangundangan, (Malang: Setara Press, 2016), hlm. 23. Lihat juga Bagir Manan, Dasar-Dasar Perundang-undangan Indonesia, (Jakarta: IN-HILL-CO, 1992), hal. 7.

\section{Jurnal}

Anwar Jasie, Dewan Perwakilan Daerah Lembaga Legislatif Tanpa Legislasi, Khazanah Hukum Volume 2, Nomor 1, (April 2020). 
Bagus Hermanto, Nyoman Mas Aryani, Ni Luh Gede Astariyani, Penegasan Kedudukan Penjelasan Suatu UndangUndang: Tafsir Putusan Mahkamah Konstitusi, Jurnal Legislasi Indononesia Volume 17, Nomor 3, (September 2020).

Enny Nurbaningsih, Implikasi Putusan Mahkamah Konstitusi Nomor 92/ PUU-X/2012 dan Alternatif Model Hubungan Kelembagaan Terkait Pembentukan Undang-Undang, Jurnal Mimbar Hukum Volume 27, Nomor 1, (Februari 2015),

Fajar Laksono Soeroso, Aspek Keadilan dalam Sifat Final Putusan Mahkamah Konstitusi, Jurnal Konstitusi ,Volume 11, Nomor 1, (Maret 2014).

Fadzlun Budi Sulistyo Nugroho, Sifat Keberlakuan Asas Erga Omnes dan Implementasi Putusan Mahkamah Konstitusi, Jurnal Gorontalo Law Review Volume 2, Nomor 2, (Oktober 2019).

Hezron Sabar Royua Tinambunan dan Dicky

Eko Prasetio, Rekonstruksi Konstitusi

Dalam Regional Representative Dewan

Perwakilan Daerah Terhadap Fungsi

Legislatif, Masalah- Masalah Hukum

Jilid 48, Number 3, (Juli 2019).

John Coakley, The Stare Revival of Bicameralism , The Journal of Legislative Studies, Volume 20, Number 4. (July 2014).
Khamami Zada, Kewenangan Legislasi Dewan Perwakilan Daerah dalam Reformasi Kelembagaan Perwakilan Pasca Putusan Mahkamah Konstitusi, Jurnal Cita Hukum, FSH UIN Syarif Hidayatullah Jakarta Volume 3, Nomor 1, (Juni 2015).

Kusnu Goesniadhie Slamet, Harmonisasi Hukum dalam Perspektif Perundangundangan, Jurnal Hukum Volume 11, Nomor 27, (September 2004).

Maruarar Siahaan, Peran Mahkamah Konstitusi dalam Penegakan Hukum Konstitusi, Jurnal Hukum Volume 16, Nomor 3, (Juli 2009).

Miguel Herrero de Miñón, The Passing of Bicameralism, The American Journal of Comparative Law, Volume 23, Number 2 (Spring 1975), Published by: American Society of Comparative Law is collaborating with JSTOR to digitize, preserve and extend access to The American Journal of Comparative Law.

Mohammad Agus Maulidi, Problematika Hukum Implementasi Putusan Final dan Mengikat Mahkamah Konstitusi Perspektif Negara Hukum, Jurnal Hukum Ius Quia Iustum Volume 24, Issue 4, (Oktober 2017).

Pan Mohamad Faiz dan Muhammad Reza Winata, Respons Konstitusional Larangan Calon Anggota Dewan Perwakilan Daerah sebagai Pengurus Partai Politik (Constitutional Response 
Concerning the Prohibition for Regional Representative Council Candidates as Political Party Officials), Jurnal Konstitusi Volume 16, Nomor 3 , (September 2019).

Radita Ajie, Batasan Pilihan Kebijakan Pembentuk Undang-undang (Open Legal Policy) dalam Pembentukan Peraturan Perundang-undangan Berdasarkan Tafsir Putusan Mahkamah Konstitusi (Limit To Open Legal Policy In Legislation Making Based on Constitutional Court Decision), Jurnal Legislasi Indonesia Volume 13, Nomor 02 (Juni 2016).

Salmon E.M. Nirahua, Kedudukan dan Kewenangan Dewan Perwakilan Daerah dalam Sistem Ketatanegaraan Indonesia, Jurnal Hukum Volume 18, Number 4, (Oktober 2011).

Sapto Budoyo, Konsep Langkah Sistemik Harmonisasi Hukum dalam Pembentukan Peraturan Perundangundangan, Jurnal Ilmiah CIVIS Volume IV, Nomor 2, (Juli 2014).

Tohadi, Dian Eka Prastiwi, dan Reni Suryani, Larangan Pengurus (Fungsionaris) Partai Politik sebagai Bakal Calon Anggota Dewan Perwakilan Daerah pada Pemilu 2019, Jurnnal Surya Kencana Satu: Dinamika Masalah Hukum dan Keadilan Volume 11 Nomor 2 (Oktober 2021).

\section{Peraturan Perundang-undangan}

Undang-Undang Dasar Negara Republik Indonesia Tahun 1945 (setelah Amandemen).

Undang-Undang Republik Indonesia Nomor 12 Tahun 2011 tentang Pembentukan Peraturan Perundang-undangan. Lembaran Negara Republik Indonesia Tahn 2011 Nomr 82. Tambahan Lembaran Negara Republik Indonesia Nomor 6109.

Undang-Undang Republik Indonesia Nomor 7 Tahun 2017 tentang Pemilihan Umum Lembaran Negara Republik Indonesia Tahun 2017 Nomor 182 dan Tambahan Lembaran Negara Republik Indonesia Nomor 6109.

Putusan Mahkamah Agung Republik Indonesia Nomor $65 \mathrm{P} / \mathrm{HUM} / 2018$, tertanggal 25 Oktober 2018.

Putusan Mahkamah Konstitusi Republik Indonesia Nomor 30/PUU-XVI/2018 tanggal 23 Juli 2018.

Keputusan Komisi Pemilihan Umum Nomor 1130/PL.01.4-Kpt/06/KPU-IX/2018 tanggal 20 September 2018 tentang Penetapan Daftar Calon Tetap Perseorangan Peserta Pemilihan Umum Anggota Dewan Perwakilan Daerah Tahun 2019. 